\title{
Contextualizing Disruptive Technologies in Media Practice and Management
}

\author{
Nelson Obinna Omenugha* \\ Doctorate Scholar and Teaching Assistant, School of Films and TV Arts, Xi'an Jiaotong-Liverpool University, China
}

Submission: March 26, 2019; Published: April 04, 2019

*Corresponding author: Nelson Obinna Omenugha, Doctorate Scholar and Teaching Assistant, School of Films and TV Arts, Xi' an JiaotongLiverpool University, Suzhou, China

\begin{abstract}
The paper sets out to offer understanding into the 'disruptiveness' of technology. Termed disruptive technologies, the discourse was situated and discussed within the context of the influence of new media technologies on media practice and management. The study examines the concept of technology as well as x-rays the implication of the activities of the new media technologies in media practice and management. It opines that the emergence and development of new media technologies generate changes that present opportunities and challenges to media practice and management. Particularly, the discourse recognizes the new ways and manners in which the activities of these media technologies are creating new jobs and tasks; that ultimately require new skills to harness and manage. It also considers the threats faced by the traditional media and argues that the management needs strategic thinking that recognizes and appreciates the impact of new media technologies on traditional media in other to develop managerial capabilities that would cushion and complement the technological effects on them. The paper is a conceptualized discourse; conducted by interpreting literature with shared research interest. As technology and people can mutually influence each other; to shape the society they operate in, this discourse presents insight to the media management on typical changes occurring in businesses as a result of the presence of new media technologies. This potentially prepares management on strategy required to harness technological gains to achieve organizational aims and build robust business environment.
\end{abstract}

Keywords: Disruptive; Technology; Innovation; New Media; Media Practice; Management; Managerial Capabilities; Content; Polymediation; Digitalization

\section{Introduction}

Technology is defined as the application of science to solve the problems of daily life experienced in activities such as communication, education, health, agriculture, banking, and logistics. Within this context, technology is considered not merely a product of modern age such as smart phones or laptops which people refer to when subject of technology comes up. Rather, technology could largely be considered as a product of influence that shapes and improves human society. The influence of the technological product advances as technology evolves. For instance, just as the emergence of digital and interactive technologies shapes the way we conduct our contemporary activities and lives, the era of fire and stone tools were important form of technology during the Stone Age that also helped change how premodern humans lived and survived. Hence, technology influences all aspect of lives - premodern and contemporary irrespective. However, not everyone has equal access to technology as technological advancement creates changes that result to ever greater inequalities; termed digital divide. The Organization for Economic Co-operation and Development (OECD) defines the digital divide as 'the gap between individuals, households, businesses and geographic areas at different socioeconomic levels with regards to both their opportunities to access information and communication technology (ICTs) and to their use of the Internet for wide variety of activities' [1].

Within the context of technology and media, both are interwoven and neither can be separated in terms of contemporary media practice and management. Media refers to all print, electronic and new digital means of communication among users. From the advent of printing and electronic press, technology has influenced how and where information is processed and disseminated. However, today, there is a new focus on new digital (new media technologies) as it is impossible to discuss media practice and ways that societies communicate without addressing the increasingly pace of technology. Moreover, fundamental changes are seen to be occurring in the media space as a result of the activities of the new media technologies and digital platforms. Hence, when one considers and talks about how societies engage with media, new media technologies are considered essentially because of the fundamental changes it has to the societies and media space. 


\section{Global Journal of Archaeology \& Anthropology}

New Media Technologies, Disruptive Technology and Disruptive Innovation

The new media technologies refer to the interactive and digital technologies which aid communication and information management among users. They include the mobile computing device such as smart phone; the streaming audio and video gadget like the digital camera; email services, web sites, virtual reality environments and social networking platforms. Practically, these platforms are internet-enabled and adjudged impacting and changing the ways and approaches activities of established (traditional) media are conducted. This also include generating new skills requirement, new tasks and multiple ways to access, create, produce and disseminate content. The changes brought by these digital technologies and platforms are considered disruptive; at least within the context that things do not remain the same when these technologies are applied. Hence, this disruptiveness implies and does demonstrate that there has been fundamental unsettling of the conventional and the routine media practice and which could present both challenges and opportunities to the traditional media depending on the variables at play in the particular context. As such, "disruptive" can have both negative and positive connotations and which will also both applied in the rest of this discourse.

The concept of disruptive technologies was introduced by a researcher, Christensen Clay to distinguish between sustaining and disruptive technologies [2]. Christensen argues that there is repeated pattern of incumbent business failure due to new, low end products introduced by small innovating firms. This happens because usually, the existing market leaders choose to concentrate on their core markets rather than adopt the new and initially weaker technology, until a tipping point is reached when the new technology takes over the market causing the big firms to fail. Within the context of media and communication industry, scholars such as Picard \& Abendroth [3,4] have discussed how radical innovations are impacting on the industry today, noting the influx of 'smart' technologies disrupt the way contemporary media operate as well as how content is developed, consumed and shared. Moreover, the convergence between new media technologies and digitalization in media production process and management practice has led to multi-skill, multi-task and multi-media jobs in the newsroom. This aspect has influenced the news production processes (such as enhancing news quality, online dissemination) and media management practice (such as coordination of entire news packaging process, decision making). As a result of these, some traditional news outlets have found themselves on a downward spiral while some new media enterprises are on the rise. In the United States, for example, Google, BuzzFeed, Yahoo News, Flip board, YouTube, Facebook, etc.; in Korea, Naver and Daum, and in Nigeria, Facebook, Twitter, Blogs and YouTube represent some of the new giants that emerged through digital disruption of the media market [5].

Media industry ecosystem has undergone and continues to witness transformations due to emergence of disruptive innovations. These disruptive innovations are based on new and disruptive technologies. Disruptive technologies are technologies that introduce a different performance package from mainstream technologies and are inferior to mainstream technologies along the dimensions of performance that are most important to mainstream customers. As such, in their early development they only serve niche segments that value their nonstandard performance attributes. Subsequently, further development raises the disruptive technology's performance on the focal mainstream attributes to a level sufficient to satisfy mainstream customers. While improved, the performance of the disruptive technology remains inferior to the performance offered by the established mainstream technology, which itself is improving as well. However, technology disruption occurs when, despite its inferior performance on focal attributes, the new technology displaces the mainstream technology from the mainstream market [6]. Essentially, the dynamics of disruptive technologies are characterized by three aspects: incumbent technologies that are displaced from the mainstream market by technologies that underperform them on the performance dimensions that are most important to mainstream consumers; mainstream consumers who shift their purchases to products based in the invading technology, even though those products offer inferior performance on key performance dimensions; and incumbent firms that do not react to disruptive technologies in a timely manner $[6,7]$.

The disruptive innovations construed within polymediation and media digitalization -have transformed the rules dominating media industry [8]. When industry ecosystem incumbents have dynamic organizational capability and make necessary strategic changes, they could exploit disruptive innovations. Thus, as crucial variables; managers' cognitive capabilities, dynamic organizational capabilities, and strategic changes share key relationships [2]. Moreover, research by Jones \& Salter [9] have shown that Media industry ecosystem incumbents could exploit innovations only when they create necessary dynamic organizational capabilities. The basis of creating these dynamic capabilities lies in development of managerial cognitive capabilities. Therefore, it is important for organizations to understand that development of managers' cognitive capabilities on the one hand helps the better understanding of disruptive innovations and it is the basis of dynamic organizational capabilities and strategic changes on the other hand. In this regard, exploiting disruptive innovation does not occur without the reconfiguration of management capabilities. Sandström, Berglund, \& Magnusson [10] contend that dynamic organizational capabilities are means to achieving organizational strategic objectives.

Disruptive technologies such as the new media technologies create new rules and system for the management. For instance, the new media technologies bring about digital systems that provide media managers with the ability to develop their skills and conduct tasks through the application of special visual effects 
in their news packages and online placement. Such visual effects afford the opportunities for the media managers to re-design, polish, add graphic designs and perform other creative tasks in news production [11]. The emergence and dominance of these new rules and system has considerable impacts on incumbents in industry ecosystem. Thus, the recognition of media industry ecosystem dynamics helps media managers to set the priorities of strategic changes in order to preserve value-creation ability and to improve organization competitive position in that ecosystem. That is to say, for media managers, cognitive capabilities are vital in terms of understanding ecosystem dynamics and triggering strategic changes.

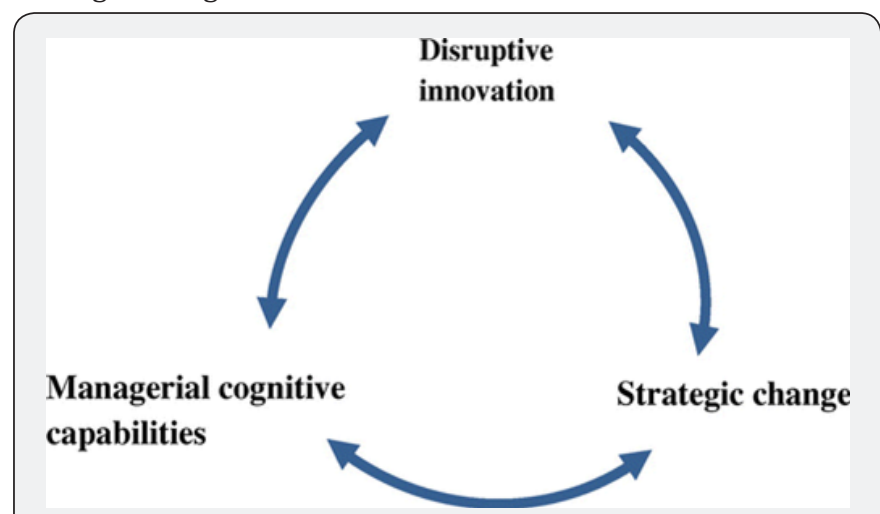

Figure 1: Relations between disruptive innovation, managerial cognitive capabilities and strategic change [28].

As shown in Figure 1, the disruptive innovation, managerial cognitive capabilities and strategic change are mutually interrelated. The emergence of disruptive innovation creates its own winners and losers. Winners in this context are media organizations that have the required capabilities to take advantage of innovation. The benefits of an innovation in industry are distributed between different groups such as innovators, customers, suppliers, imitators, and other followers. Therefore, the distribution of innovation-related benefits is based on three fundamental building blocks: the appropriability regime, dominant design paradigm and complementary assets $[12,13]$.

From the perspective of business management, these new digital and technology-driven rules and standards provide for the emergence of dominant design paradigm. As the dominant design emerges, competition shifts to price and away from design. Competitive success then shifts to a whole new set of variables. Scale and learning become much more important, and specialized capital gets deployed as incumbents seek to lower unit costs through exploiting economies of scale and learning. In this regard, reducing uncertainty over product design provides an opportunity to amortize specialized long-lived investments [12]. In addition, complementary assets provide set of capabilities that for instance, the media organizations need to take advantage of these innovations. Whether origin of innovation is inside the company (which means the company is innovator) or in institutional context, these complementary assets or capabilities are needed in order to take advantage of innovation. In almost all cases, the successful commercialization of innovation requires that the know-how in question be utilized by the management in conjunction with other capabilities or assets. Services such as marketing, competitive manufacturing, and after-sales support are almost always needed. These services are often obtained from complementary assets which are specialized. In some cases, as when the innovation is systemic, the complementary assets may be other parts of a system. Even when an innovation is autonomous, as with plug compatible components, certain complementary capabilities or assets will be needed for successful commercialization [12]. Christensen \& Overdorf [2] note that sustaining innovations are nearly always developed and introduced by established industry leaders; however, those same companies never introduce - or cope well with - disruptive innovations.

Disruptive innovation does not necessarily involve cuttingedge new technology, as radical innovation does. Sometimes, innovations could be disruptive in that they didn't address the next-generation needs of leading customers in existing markets. They had other attributes, of course, that enabled new market applications to emerge - and the disruptive innovations improved so rapidly that they ultimately could address the needs of customers in the mainstream of the market as well. Hence, disruptive innovation involves the application of a relatively new, but not cutting-edge technology to a new product category [14]. Technology-driven disruptive typically emerges from startup firms that focus on upstream Research and Development (R\&D) exploration activities and unfolds through uncertainties, intermittent evolutionary and complex processes that involve multiple actors. A disruptive business model unfolds when a market emerges for the technology and downstream firms begin to exploit market opportunities [15].

\section{Polymediation and Media Digitalization as Disruptive Factors}

This section discusses polymediation and media digitalization as disruptive factors; $\mathrm{x}$-raying conditions and nature of technological disruptions they represent. They consider that media practice and management faces challenges that require the understanding and appreciation of the new tasks and their implication to traditional media management practice.

\section{Polymediation}

Polymediation represents the condition that disruptive technologies stemming from other industries or emerging segments transform the rules dominating media industry ecosystem. Polymediation is a word that is meant to signify the idea that we now live in the ultimate co-created mediated reality. It is with us and all around us - always - already we exist in the media. We are continually weighing, measuring, filtering, balancing, discarding, and constructing our mediated reality. Polymediation is not just a product; it is an ongoing process [16]. 
Some of the characteristics of polymediation that may shape our performances of identity include ubiquity, shapeshifting authorship, the simultaneous fragmentation and merging of identity and division/communality [16]. Ubiquity is a fundamental piece of the polymediation equation. In this context, the term ubiquity refers to the widespread and often simultaneous accessibility and presence of media. The saturation of new media platforms in our daily lives has altered how we seek information and how we connect with others and maintain relationships, while also providing some opportunities for the shifting nature of content authorship and ownership. Messages are mediated by different authors in different contexts. Individual users of new media technologies have greater power to create and distribute content; making users not just consumers, but also producers [16]. A third element of polymediation is the paradox of the fragmented/unified performance of identity. Our presences online are all a part of who we are and are performed specifically for others. Not everyone sees all of these performances; they are intended for different audiences. Therefore, our self is decentered but interconnected. All of our performances, online and offline, constitute the self, which means the ways in which technology fragments and merges identity performances [16]. More information, more media outlets, and more social networking can do as much to divide us as unite us. While polymediation has the potential to divide us, it also creates possibilities for communality and the creation of shared meanings.

Polymedia shift the emphasis from discrete technologies or platforms to media environments. Rather than focus on the properties or affordances of specific technologies, polymedia shifts our attention to how users navigate media environments and choose platforms from a range of communicative opportunities [17]. Polymedia is an emerging environment of communicative opportunities that functions as an "integrated structure" within which each individual medium is defined in relational terms in the context of all other media [18].

Thus, the emergence of digital media or digitization of media forms the foundation of polymediation. Digital media have led to domination of connective action logic on social life. Digital media networking can change the organizational game, given the right interplay of technology, personal action frames, and, when organizations get in the game, their willingness to relax collective identification requirements in favor of personalized social networking among followers. The logic of collective action that typifies the modern social order of hierarchical institutions and membership groups stresses the organizational dilemma of getting individuals to overcome resistance to joining actions where personal participation costs may outweigh marginal gains, particularly when people can ride on the efforts of others for free and reap the benefits if those others win the day. In short, conventional collective action typically requires people to make more difficult choices and adopt more selfchanging social identities than DNA based on personal action frames organized around social technologies. The spread of collective identifications typically requires more education, pressure, or socialization, which in turn makes higher demands on formal organization and resources such as money to pay rent for organization offices, to generate publicity, and to hire professional staff organizers. Digital media may help reduce some costs in these processes, but they do not fundamentally change the action dynamics [8].

The logic of connective action foregrounds a different set of dynamics from the ones just outlined. At the core of this logic is the recognition of digital media technologies as organizing agents [8]. When these interpersonal networks are enabled by technology platforms of various designs that coordinate and scale the networks, the resulting actions can resemble collective action, yet without the same role played by formal organizations or transforming social identifications. In place of content that is distributed and relationships that are broken by hierarchical organizations, social networking involves co-production and codistribution, revealing a different economic and psychological logic: co-production and sharing based on personalized expression [8]. Digital technologies have transformed the rules dominating many industries including media industry. Digital technologies in media industry are disruptive. These technologies are the origin of many disruptive innovations in media industry.

The media industry has already been transformed by several waves of digitalization. To thrive, media enterprises will have to keep technology at the heart of what they do, helping them create compelling content and reach new audiences [19]. Digitalization has become so important that the boundary between the media and technology industries has broken down. This has implications for both traditional media companies and digitally native startups. However, research has identified a number of digital initiatives that will be the building blocks media companies can use to transform their business. The initiatives are grouped into three themes - personalization and contextualization, content fragmentation, and partnerships and industrialization - which are believed will be of importance to the digital transformation of the media industry.

\section{Personalization and Contextualization}

As more content is produced, marketers and content creators need to produce personalized content and personalized advertising to engage consumers facing information overload. Both these developments will raise data privacy and security issues that firms need to resolve ethically and transparently.

\section{Content Fragmentation}

Content is being distributed across an increasing number of platforms, devices and media. For companies, this presents challenges (to keep their audiences engaged) and opportunities. Communities of content, which have sprung up on instant messaging and social platforms, will be fertile ground for 
advertisers, as long as their strategy is adapted to the group they are targeting.

\section{Partnerships and Industrialization}

As the creation and distribution of content have become fragmented, partnerships in the media industry have become more important. Technology is enabling enterprises to partner with their audiences to fund or co-create innovative content. Companies will also need to harness technology effectively, setting it at the heart of a digital organization, balancing creativity in content creation with industrializing digital processes such as production and distribution [19]. Digitalization as disruptive innovation has influenced different parts of media industry in both print and electronic media organizations. In different studies, the impacts and consequences of digitalization on media organizations have been investigated. In some of them, the general aspects of digitalization impacts on media industry have been described [20]. Some other researches have been devoted to digitalization impacts on Public Service Media (PSMs) [2123].

However, the importance of accurate understanding of disruptive innovations by top managers and the impact of proper understanding of these innovations on strategic decision-making have been addressed in many researches. Saltzi \& Dickinson [24] note that the traditional news organizations are undergoing Table 1: Dimensions and indicators of media digitalization as disruptive innovation in media industry [28].

\begin{tabular}{|c|c|c|}
\hline Variable & Dimension & Index \\
\hline \multirow{10}{*}{ Media digitalization as disruptive innovation } & \multirow{5}{*}{ Personalization and Contextualization } & Personalized advertising \\
\hline & & Personalized content \\
\hline & & Phygital \\
\hline & & Data privacy and transparency reform \\
\hline & & Advertising \\
\hline & \multirow{3}{*}{ Context Fragmentation } & Communities of content \\
\hline & & OTT and OTT2 \\
\hline & & Content access and IP right \\
\hline & \multirow{2}{*}{ Partnership and Industrialization } & Engagement, co-creation, crowdsourcing \\
\hline & & Flexible, predictive, precise creation \\
\hline
\end{tabular}

The dominant logic reflects both managerial cognitive capabilities and strategic change priorities. The measurement of new dominant logic attributes shows the extent of organization willingness to digitalization as disruptive innovations. In addition to the extent of new dominant logic dominance, the results of this evaluation illustrate the priority of digitalization in strategic plans of IRIB. Identifying the priorities of strategic actions in view of mangers also illustrates priorities of strategic changes (Table 2).

While many media organizations are still getting to grips with using social media effectively, others are still moving one or two steps ahead of business with their use of new media technologies. This is shown by the explosion in the digital mobile app market and wearable technologies that have become substantial changes in terms of strategic thinking and work organization which ultimately affect the media work and management practice. Therefore, there is a sound relationship between the extent of recognition of disruptive innovations by managers and the quality of strategic decisions. Media digitalization with multiple waves of disruptive innovations has widespread outcomes and consequences for every type of media. Thus, media managers require proper understanding of media digitalization and its impacts on different aspects of business and organization actions.

\section{Media Digitalization}

Media digitalization as a disruptive innovation is caused by different drivers. Demographic factors, new consumer behaviors and expectations, ecosystem challenges and technology processes are four types of elements that act as disruptive has influences on media. These impacts are articulated as three dimensions of personalization and contextualization, content fragmentation, partnership and industrialization. Understanding of disruptive innovation by managers is measurable based on their understanding of these dimensions [25-28]. These dimensions are components of media digitalization for media organization. The dimensions and indicators of media digitalization as disruptive innovation are illustrated in Table 1. innovation drivers. Media digitalization as disruptive innovation

the latest 'must-have' gadgets on the market. Tagged as 'digital disruption technologies', these new systems now put pressure on business owners to bring together their IT department and their marketing team to collaborate on sales strategies. Thus, the one-way physical marketing of olden times has long gone. Yes, it was much simpler in the past when you could take out; for instance, a print advert in a newspaper or magazine, or even in more recent times encouraging people to buy from you through a well-targeted email campaign. In these days of social media marketing, it is definitely a two-way street where social interaction and trust building are the key to selling your brand. Today the customer is more in charge of marketing efforts than in the past. They are digitally connected to diverse businesses and media sites and empowered to review and patronize content, product and services as well as provide feedback; even without 


\section{Global Journal of Archaeology \& Anthropology}

ever having to physically meet with such business or media site. The goal with disruptive technology is to get businesses Table 2: Old and new dominant logic in PSM: categories and indicators [28].

\begin{tabular}{|c|c|c|c|c|c|}
\hline \multicolumn{3}{|c|}{ Dominant Logic } & \multicolumn{3}{|c|}{ New Dominant Logic } \\
\hline Dimensions & \multicolumn{2}{|r|}{ Indicators } & Dimensions & \multicolumn{2}{|r|}{ Indicators } \\
\hline Content portfolio and platform & - & Mass relevant genres & Content portfolio and platform & & $\begin{array}{l}\text { - } \quad \text { Cross genres } \\
\text { Special interest genres }\end{array}$ \\
\hline Channel and distribution & & - $\quad$ Linear & Channel and distribution & & $\begin{array}{cc}- & \text { Non-Linear } \\
- & \text { Dual screening } \\
\text { - } & \text { User interface } \\
& \text { Personalization }\end{array}$ \\
\hline Structure & - & - $\quad$ Siloed provider & Structure & - & Integrated provider \\
\hline Audience & - & $\begin{array}{l}\text { - Consumer } \\
\text { Traditional segmentation }\end{array}$ & Audience & - & $\begin{array}{l}\text { - Co-creator } \\
\text { New segmentation }\end{array}$ \\
\hline Technology & & - $\quad$ Electronic & Technology & & Digital \\
\hline
\end{tabular}

\section{Conclusion}

Technology has shaped media practice and management all over the world. This assumption recognizes that new technology, along with globalization and the conglomeration of media, is causing shift from the traditional and bringing changes in the ways and manners media content is accessed, generated, produced and disseminated. This change has so been described as disruptive as impact on media space is arguably visibly fundamental. The rise of disruptive technologies and business models in the media sector is causing considerable concern among sector management, many of who seem unprepared to deal with increased, and new, competitive pressures. Management are particularly concerned about the use of social media, customer companies face a barrage of new threats, from new entrants such as Netflix disrupting traditional television, to large advertising platforms such as Facebook, disrupting the traditional revenue models of media organizations. New technologies such as such as the Internet, mobile smart phones and other digital gadgets are likely to create a host of new threats, from improved competitive business models for competitors, to new entrants taking market share or completely disseminating markets as such.

\section{References}

1. OECD (2001) Bridging the Digital Divide: Issues and Policies in OECD Countries. OECD: Paris, France.

2. Christensen CM, Overdorf M (2000) Meeting the challenge of disruptive change. Harvard Business Review, p. 1-10.

3. Picard RG (2003) Cash Cows or Entrecote: Publishing C and Disruptive Technologies. Trends in Communication 11: 127-136.

4. Abendroth M (2013) Understanding Disruptive Innovation in the Media Sector: Post-Conference Report.

5. The New York Times (2014) Innovation.

6. Adner R (2002) When are technologies disruptive? A demand-based view of the emergence of competition. Strategic Management Journal 23: 667-688. experience, cloud and broadband based technologies. Media and media organizations closer to their target audience with something innovative on their chosen device.
7. Dannels E (2004) Disruptive technology reconsidered: A critique and research agenda. The Journal of Product Innovation Management 21: 246-258.

8. Bennett WL, Segerberg A (2012) The logic of connective action: Digital media and the personalization of contentious politics. Information. Communication \& Society 15: 739-768.

9. Jones J, Salter L (2012) Digital Journalism. Sage Publications Ltd, Los Angeles, USA, p. 37.

10. Sandström C, Berglund H, Magnusson M (2014) Symmetric assumptions in the theory of disruptive innovation: Theoretical and managerial implications. Creativity and Innovation Management 23: 472-483.

11. Pavlik JV (2001) Journalism and new media. Columbia University Press, USA.

12. Teece DJ (1986) Profiting from technological innovation: Implications for integration, collaboration, licensing and Policy 15: 285-305.

13. Markides C (2006) Disruptive innovation. In need of better theory. The Journal of Product Innovation Management 23: 19-25.

14. Govindarajan V, Kopalle PK, Danneels E (2011) The effects of mainstream and emerging customer orientations on radical and disruptive innovations. Journal of Product Innovation Management 28: 121-132.

15. Habtay SR, Holmén M (2014) Incumbents' responses to disruptive business model innovation: The moderating role of technology vs. market-driven innovation. International Journal of Entrepreneurship and Innovation Management 18: 289-309.

16. Herbig A, Herrmann AF, Tyma AW (2015) Beyond New media, Lanham, Lexington Books, USA, p. 15.

17. Madianou M (2016) Ambient co-presence: Transnational family practices in polymedia environments MIRCA. Global Networks, 16: 183201.

18. Madianou M, Miller D (2012) Polymedia: Towards a new theory of digital media in interpersonal communication. International Journal of Cultural Studies 16: 69-187.

19. WEF (2016) Digital transformation of industries: Media Industry, World Economic Forum Report.

20. Jakubowicz K (2007) Public service broadcasting in the $21^{\text {st }}$ century, What chance for a new beginning? In: Lowe GF, Bardoel J, (Eds.), Nordicom, Göteborg, Europe.

21. Mei-pochtler A, Von Merey T (2014) Preparing for public broadcasting's perfect storm. BCG Report. 
22. Aggarwal N, Arthofer F, Rose J, Lind F, Rosenzweig J, et al. (2016) The digital revolution is disrupting the TV industry. BCG Perspectives.

23. Arthofer F, Hardarson A, Kon M, Lee E, Rose J (2016) The future of television, BCG Report.

24. Saltzi K, Dickinson R (2008) Inside the changing newsroom: journalists' responses to media convergence. In Aslib Proceedings 60(3): 216 $-228$.

25. Lavie D (2006) Capability reconfiguration: An analysis of incumbent responses to technological change. Academy of Management Review 31(1): 153-174.

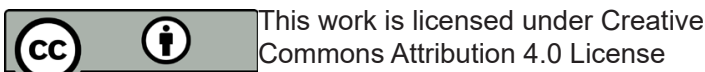

BY DOI:_10.19080/GJAA.2019.08.555743
26. Aborisade OP (2010) How Technology Transforms Journalism Business through Citizen-Reporters in Nigeria. PhD dissertation submitted to Capella University.

27. Job OI (2017) A Comparative Study of Digital Competence and Response to Digital Innovations by Korean and Nigerian Newspaper Journalists. J Mass Communication Journalism 7: 335.

28. Masoud GR (2017) Disruptive innovation in media industry ecosystem and need for improving managerial cognitive capabilities in polymediation era, Cogent Business \& Management 4: 1352183.

\section{Your next submission with Juniper Publishers} will reach you the below assets

- Quality Editorial service

- Swift Peer Review

- Reprints availability

- E-prints Service

- Manuscript Podcast for convenient understanding

- Global attainment for your research

- Manuscript accessibility in different formats

( Pdf, E-pub, Full Text, Audio)

- Unceasing customer service

Track the below URL for one-step submission https://juniperpublishers.com/online-submission.php 